Acta vet. scand. $1970,11,415-426$.

From the Department of Obstetrics and Gynaecology,

Royal Veterinary College, Stockholm, Sweden.

\title{
SYNCHRONIZATION OF OESTRUS IN HEIFERS WITH NORETHISTERONE
}

\author{
By \\ Göran Åström
}

Successful attempts to bring about synchronization of oestrus in heifers have been achieved by means of both natural and artificial progesterons (Lamond 1964). Varying conception rates have been obtained following service during the synchronized heat periods.

By simultaneous use of progesterone and oestradiol Wiltbank \& Zimmerman (1962) obtained better heat synchronization than with progesterone alone, and a conception rate among the experimental animals comparable with that of the controls. According to Ulberg (1955) and Ulberg \& Lindley (1960) synchronization of oestrus is improved when oestradiol is given on the third day after termination of treatment with progesterone. The latter two workers reported that the conception rate was no worse than with progesterone treatment alone. Wagner et al. (1963) reported similar results after treatment with CAP, (6chloro- $\Delta^{6}$-dehydro-17-acetoxyprogesterone) and oestradiol.

Norethisterone (derived synthetically from 19-nortestosterone) is partly converted to oestrogen following oral administration in rats (Edgren et al. 1966, 1967), so considering the favourable effect of combined oestrogen and progesterone treatment mentioned above, an experiment which would test the value of norethisterone (17- $\alpha$-ethynyl-19-nortestosterone) as a means of synchronization of oestrus in heifers was thought to be worthwhile. In this work special attention was given to the effect of the size of dose and to the stage of oestrous cycle when hormone treatment began. 


\section{MATERIALS AND METHODS}

The experiment took place from January to April 1967. Fifty heifers from different herds were assembled on an experimental farm together with 10 of the farm's own heifers. All the experimental animals were Swedish Red and White Cattle between 13 and 23 months old. Their weights varied from 250 to $430 \mathrm{~kg}$, and were confirmed by weighing.

The animals were kept in stalls and fed according to normal rearing standards. Two $\mathrm{kg}$ mixed concentrate (grain, oilcake and molasses) and $4 \mathrm{~kg}$ of silage (marrow-stem kale) were given every morning and $2-4 \mathrm{~kg}$ of hay together with $1-2 \mathrm{~kg}$ of straw in the afternoon. The animals' conformation was at first somewhat below average, but improved during the course of the experiment. Fifty $\mathrm{g}$ of mineral supplement and $50 \mathrm{~g}$ of calcium carbonate were given daily to each animal.

Apart from ringworm infection, the general health of the stock remained good during the whole experimental period.

During a pre-experimental period of at least five weeks and during the experiment itself, the animals' oestrous cycles were kept under observation by inspection twice daily. Clinical examinations including visual inspections of the external genitalia and rectal palpations of the cervix, uterus, and ovaries were carried out repeatedly during the pre-experimental period and during the course of the experiment. The state of the vaginal mucosa was studied by means of a glass speculum.

Guided by previous signs of oestrus and by the clinical examinations, the stage of cycle of individual heifers was confirmed when hormone administration began. Animals which showed two heat periods with a normal interval, or a single heat followed by rectal confirmation of ovulation, were included in the trials. The day of heat was taken as the first day of the cycle.

Doses of $0.2,0.6$ and $1.0 \mathrm{mg}$ of norethisterone per $\mathrm{kg}$ body weight per day were tested. Because the body weight varied for different heifers the daily amount of hormone administered varied between $50 \mathrm{mg}$ and $375 \mathrm{mg}$.

In all, the trials included 50 heifers in different stages of oestrous cycle. Ten heifers, which during the pre-experimental period had not demonstrated normal sexual activity, were excluded from the experiment. The animals were combined in trial groups so that for each dose a number of animals were in the luteal phase and the rest in the follicular phase of the cycle. The 
experiment was carried out in two stages (trial I and II). A field trial (III) was also undertaken, including 15 heifers.

\section{Trial I}

In this trial a comparison was made of the effects of oral administration of $0.2 \mathrm{mg}$ (group I A) and $1.0 \mathrm{mg}$ (group I B) of norethisterone per $\mathrm{kg}$ body weight daily for 17 days.

Twenty-six heifers were divided into two groups so that in both the average weight, age, and stage in oestrous cycle were similar (Table 1). In each group there were five heifers in the

T a ble 1. The distribution of the experimental animals over days of the oestrous cycle when hormone treatment began.

\begin{tabular}{|c|c|c|c|c|c|c|c|c|c|c|c|c|c|c|c|c|c|c|}
\hline \multirow[t]{2}{*}{ Group } & \multirow[t]{2}{*}{$\begin{array}{c}\text { No. of } \\
\text { animals }\end{array}$} & \multirow{2}{*}{$\begin{array}{l}\text { Aver. } \\
\text { age, } \\
\text { months }\end{array}$} & \multirow{2}{*}{$\begin{array}{c}\text { Aver. } \\
\text { weight, } \\
\text { kg }\end{array}$} & \multicolumn{15}{|c|}{$\begin{array}{l}\text { Day of cycle } \\
\text { luteal phase }\end{array}$} \\
\hline & & & & 1 & 2 & 3 & 4 & 5 & 6 & 7 & 8 & 9 & 10 & 11 & 12 & 13 & 14 & 15 \\
\hline I A & 13 & 16.7 & 318.5 & & & & & & 1 & & & 1 & 1 & 3 & 2 & & & \\
\hline I B & 13 & 16.0 & 319.5 & & & & & 1 & 1 & & & 2 & & 1 & 1 & & 1 & 1 \\
\hline II A & 12 & 15.1 & 287.0 & & & 2 & & 1 & & 1 & 1 & 2 & & & & 1 & & \\
\hline II B & 12 & 15.6 & 290.0 & & & & 2 & & & 1 & 1 & & & & 1 & & 3 & \\
\hline
\end{tabular}

Table 1. Continued.

\begin{tabular}{|c|c|c|c|c|c|c|c|c|c|c|c|c|c|}
\hline \multirow[t]{2}{*}{ Group } & \multirow[t]{2}{*}{$\begin{array}{c}\text { No. of } \\
\text { animals }\end{array}$} & \multirow{2}{*}{$\begin{array}{l}\text { Aver. } \\
\text { age, } \\
\text { months }\end{array}$} & \multirow{2}{*}{$\begin{array}{c}\text { Aver. } \\
\text { weight, } \\
\text { kg }\end{array}$} & \multicolumn{10}{|c|}{$\begin{array}{l}\text { Day of cycle } \\
\text { follicular phase }\end{array}$} \\
\hline & & & & 16 & 17 & 18 & 19 & 20 & 21 & 22 & 23 & 24 & 25 \\
\hline I A & 13 & 16.7 & 318.5 & 1 & & 4 & & & & & & & \\
\hline I B & 13 & 16.0 & 319.5 & 2 & & 3 & & & & & & & \\
\hline II A & 12 & 15.1 & 287.0 & 1 & 1 & 2 & & & & & & & \\
\hline II B & 12 & 15.6 & 290.0 & & 2 & & & 1 & & & & 1 & \\
\hline
\end{tabular}

follicular phase and eight in the luteal phase of the cycle. Norethisterone well mixed in $1 \mathrm{~kg}$ of mixed crushed cereal was fed individually once daily to each animal before the morning feed. On account of larger differences in live weight six heifers in group I A received $75 \mathrm{mg}$ and seven heifers $50 \mathrm{mg}$ of norethisterone per head per day. Smaller differences still made the dose consumed by individuals in the group vary between 0.17 and $0.23 \mathrm{mg}$ (a mean of $0.2 \mathrm{mg}$ ) of hormone per $\mathrm{kg}$ body weight daily. For similar reasons six heifers in group I B received $375 \mathrm{mg}$ and seven heifers $250 \mathrm{mg}$ of norethisterone per head per day. The 
dose consumed varied for individuals in this group between 0.75 and $1.15 \mathrm{mg}$ (a mean of $1.0 \mathrm{mg}$ ) of hormone per $\mathrm{kg}$ body weight daily.

\section{Trial II}

This trial was designed to compare the effect of oral administration of $0.6 \mathrm{mg}$ (group II A) and $1.0 \mathrm{mg}$ (group II B) norethisterone per $\mathrm{kg}$ body weight given daily for 17 days.

Twenty-four heifers were divided into two groups of 12 animals according to the same conditions as in trial I (Table 1). The animals in group II $A$ were fed $170 \mathrm{mg}$ of norethisterone and in group II B $280 \mathrm{mg}$ per head per day (Table 2). Individual heifers received amounts of hormone which varied in group II A between 0.50 and $0.66 \mathrm{mg}$ ( $\mathrm{a}$ mean of $0.6 \mathrm{mg}$ ) and in group II B between 0.84 and $1.04 \mathrm{mg}$ (an average of $1 \mathrm{mg}$ ) per $\mathrm{kg}$ body weight daily.

At the first and, where necessary, the second heat after termination of hormone treatment the heifers were artificially inseminated with deep-frozen semen (in pellet form) which in all cases was a single ejaculate from a bull of proven fertility belonging to Södermanland county artificial insemination association. The inseminations were carried out by two of the association's experienced technicians. The fertility of the ejaculate in question was proved by inseminations during the A.I. centre's routine activity of 32 cows and heifers.

Nine-12 days after the first heat the ovaries were examined in order to ascertain the extent of corpus luteum development. Pregnancy was confirmed by rectal examination six weeks after the last insemination.

\section{Trial III (field trial)}

Fourteen Swedish Red and White heifers and one Hereford heifer, all between 17 and 25 months old (average age 21 months), and with an estimated average weight of $400 \mathrm{~kg}$ were included in the field trial.

The heifers were allowed to run free in a large loose box with adequate trough space for all to eat at the same time. Four- $5 \mathrm{~kg}$ of mixed concentrate and about $8 \mathrm{~kg}$ of silage were given every morning, about $3 \mathrm{~kg}$ of hay and straw were fed in the afternoon.

The animals' conformation was generally above normal. All the animals underwent clinical examination before the trial's 
commencement which revealed the presence of follicles and corpora lutea in the ovaries of all but two. No systematic observation of oestrus was carried out before the trial began.

Two-hundred-and-forty $\mathrm{mg}$ of norethisterone per animal (approx. $0.6 \mathrm{mg} / \mathrm{kg}$ body weight) was given daily for 17 days in the concentrate mixture.

Observation for heat signs was undertaken by the stockman and inseminations and pregnancy diagnosis by a trained inseminator. Deep-frozen semen in pellet form from one Hereford and two Friesian bulls of high fertility was used.

The semen was tested by insemination of 351 cows and heifers in routine insemination work.

\section{Trials I and II}

\section{RESULTS}

\section{Observations during hormone treatment}

Three heifers in the group receiving $0.2 \mathrm{mg}$ norethisterone (I A) and one in the $1.0 \mathrm{mg}$ group (II B) showed heat symtoms during hormone treatment occurring at the normal interval after the last heat before treatment began. On corresponding days several other heifers in the $0.2 \mathrm{mg}$ group were seen to have a swollen vulva, a mucous discharge, somewhat open and reddened portio, a somewhat contracted uterus, and medium to large follicles in the ovaries, but no psychic signs of heat. The mucous discharge was usually copious, greyish and of varying viscosity. This symptom became more marked towards the last day of hormone treatment. In the group receiving the higher hormone level ( $0.6 \mathrm{mg}$ and $1.0 \mathrm{mg} / \mathrm{kg}$ body weight) a mucous discharge and oedema of the vulva were observed in $65 \%$ of the animals. However, almost all these animals possessed no palpable follicles, or only small ones, during the whole period of hormone treatment. In none of the groups was the occurrence of ovulation detected and no corpora lutea developed.

In 11 cases (22\% of all the experimental animals) a moderate to marked enlargement of the udder was observed during the period of treatment.

\section{Extent of heat synchronization}

Synchronization of oestrus after termination of treatment is shown in Figs. 1 and 2. The distribution of oestrus for repeating heifers is also shown. 
$\square$ = First heat after treatment

Za = Second heat after treatment

GROUP IA(0.2 mg norethisterone/kg bodyweight)

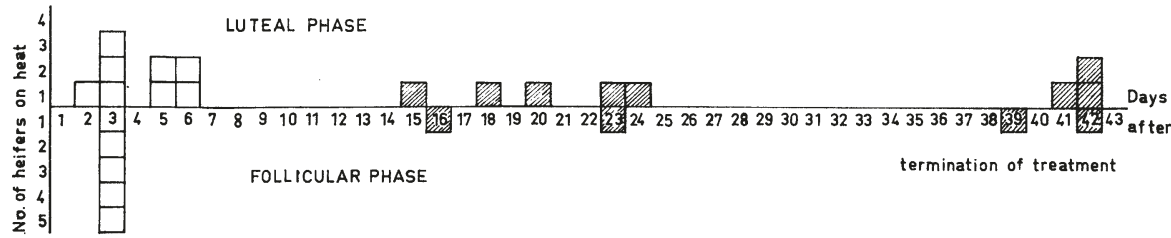

GROUP I B(1.omg. norethisterong $\mathrm{kg}$ bodyweight)

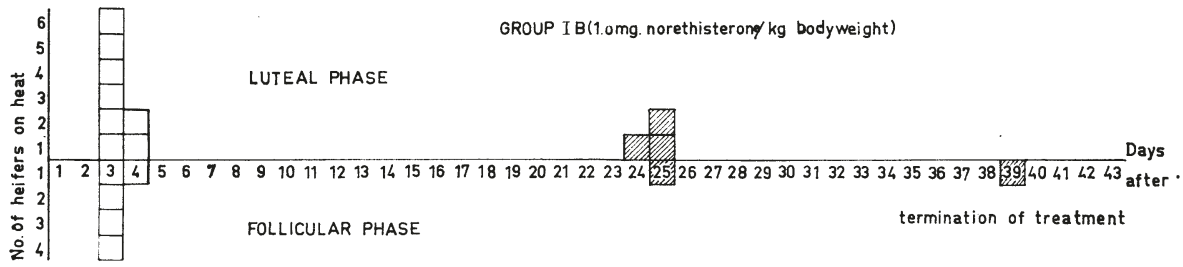

F i g u r e 1. Distribution of first and second heats after treatment of heifers with norethisterone in trial I.
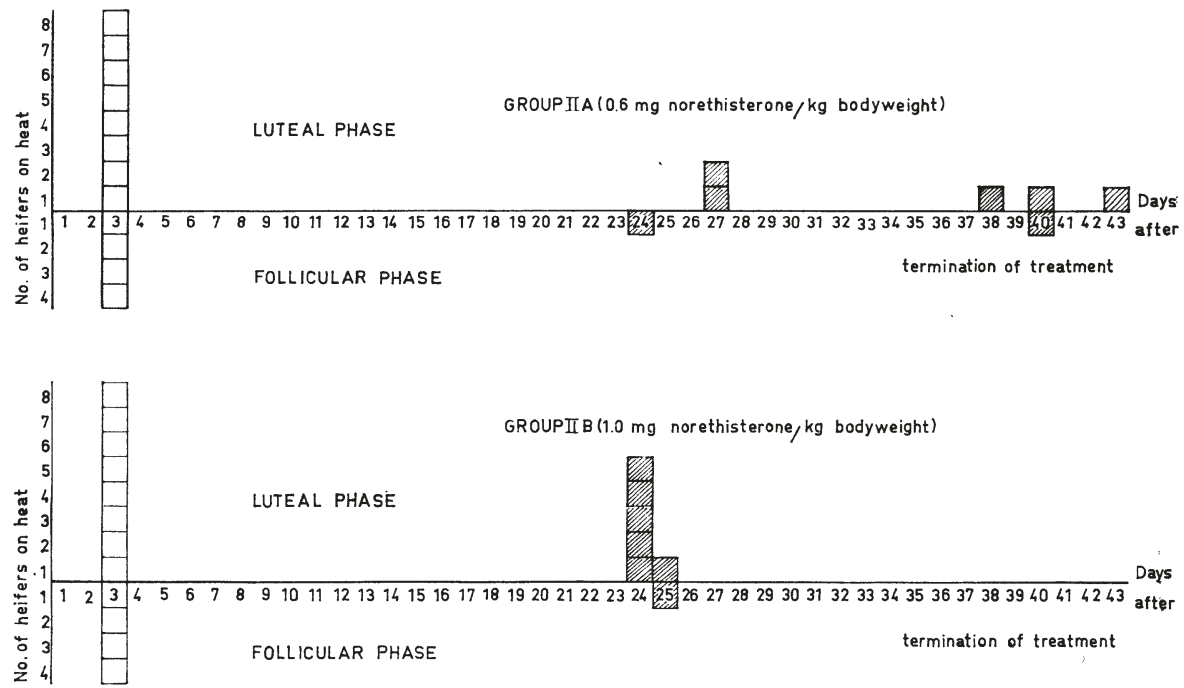

Figure 2. Distribution of first and second heats after treatment of heifers with norethisterone in trial II.

The synchronized heats were distinct and easy to confirm. Approximately half of the animals demonstrated heat symptoms during a period of $24-36 \mathrm{hrs}$. and the others during a shorter period. 
a. Ef fect of dos e size

The lowest level of hormone $(0.2 \mathrm{mg})$ produced poor heat synchronization (Fig. 1). Oestrus appeared from the second to the sixth day and eight of 13 heifers $(62 \%)$ were on heat on the third day after withdrawal of treatment.

With the other doses heat synchronization was very good and no difference in effect was demonstrated between the two doses $0.6 \mathrm{mg}$ and $1.0 \mathrm{mg}$ norethisterone per $\mathrm{kg}$ body weight (Fig. 2). In all 34 of 37 heifers (92\%) which had received $0.6 \mathrm{mg}$ or 1.0 mg norethisterone came on heat on the third day after termination of treatment and three one day later.

Three of 13 heifers $(23 \%)$ on $0.2 \mathrm{mg}$, six of $12(50 \%)$ on $0.6 \mathrm{mg}$ and 19 of 25 (76\%) on $1.0 \mathrm{mg}$ showed metoestral bleeding after heat. The bleeding was more pronounced than usual.

Palpation of the ovaries on the 9th-12th day after the appearance of synchronized oestrus showed that corpora lutea had developed in eight of 13 heifers which had received the $0.2 \mathrm{mg}$ level of hormone. In two of the others were found large ovarian cysts of lutein type. Two heifers at the $0.6 \mathrm{mg}$ level very probably had cystic corpora lutea while all other heifers at the $0.6 \mathrm{mg}$ and $1.0 \mathrm{mg}$ dose level had normal corpora lutea.

\section{b. Effect of cyclestage}

Only with the lowest dose of hormone did there appear any connection between stage of cycle and heat synchronization. Heifers receiving this dose which were in the luteal phase when treatment began, came on heat between the second and sixth day after withdrawal of the hormone, while heat in all heifers in the follicular phase appeared on the third day (Fig. 1). On the other hand neither ovulation failure nor the development of ovarian cysts and cystic corpora lutea that occurred could be attributed to the stage of the heifers' cycle when hormone treatment began.

\section{Fertility}

a. Effect of dos esize

Conception rates for the different groups are evident from Table 2. Conception rates for the $0.2 \mathrm{mg}$ group at the first two inseminations were $30.8 \%$, for the $0.6 \mathrm{mg}$ group $58.3 \%$ and for the two $1.0 \mathrm{mg}$ groups together it was $76.0 \%$. 
T a b l e 2. Conception rate following first and second inseminations after heat synchronization treatment.

\begin{tabular}{cccccc}
\hline Group & $\begin{array}{c}\text { No. of } \\
\text { animals }\end{array}$ & $\begin{array}{c}\text { Dose } \\
\mathrm{mg} / \mathrm{kg}\end{array}$ & $\begin{array}{c}\text { No. of conceptions after } \\
\text { 1st ins. }\end{array}$ & $\begin{array}{c}\text { Total conception } \\
\text { 2nd ins. } \\
\text { rafter }\end{array}$ \\
\hline I A & 13 & 0.2 & 1 & $3^{\star \star}$ & 30.8 \\
I B & 13 & 1.0 & 8 & 2 & 76.9 \\
II A & 12 & 0.6 & 5 & 2 & 58.3 \\
II B & 12 & 1.0 & 5 & 4 & 75.0 \\
III & $15^{\star}$ & 0.6 & 10 & $3^{\star \star}$ & 92.9 \\
\hline
\end{tabular}

* one heifer in group III, owing to technical reasons, was not inseminated at the first heat.

* * two heifers in groups I A and III respectively were not inseminated at the second heat.

\section{b. Effect of cyclestage}

The only heifers which conceived after the first insemination in the $0.2 \mathrm{mg}$ group was in the follicular phase when hormone treatment began. The combined material in the other groups in which the stage of cycle was studied (groups I B, II A, and II B) shows that 24 animals were in the luteal phase and 13 in the follicular phase of the cycle when hormone treatment began. The first insemination produced pregnancy in $\mathbf{1 0}$ heifers in the luteal phase $(41.7 \%)$ and in eight in the follicular phase $(61.5 \%)$. Overall conception rates after two inseminations were $75.0 \%$ for the group in the luteal phase and $61.5 \%$ in the follicular phase.

c. Length of cycle of repeating heifers

The length of cycle in heifers not conceiving after the first insemination is shown in Table 3. Only three out of 12 heifers $(25 \%)$ in the $0.2 \mathrm{mg}$ group returned after a normal interval

T a b l e 3. Interval between first and second heats after synchronization treatment.

\begin{tabular}{cc}
\hline $\begin{array}{c}\text { Dose } \mathrm{mg} / \mathrm{kg} \\
\text { body weight }\end{array}$ & \multicolumn{1}{c}{ Interval, days } \\
\hline 0.2 & $9,13,15,15,18,18,20,36,39,39,39,39$ \\
0.6 & $21,24,24,35,37,37,40$ \\
1.0 & $21,21,21,21,21,21,21,21,22,22,22,36$ \\
\hline
\end{tabular}


(18-25 days) and three out of seven heifers $(42.9 \%)$ in the $0.6 \mathrm{mg}$ group. In the $1.0 \mathrm{mg}$ group 11 out of 12 heifers (92\%) returned after a normal interval.

\section{Trial 11 I}

No heifer was observed on heat during the period of hormone administration. However, several demonstrated swelling of the external genitalia and a somewhat grey, viscous discharge from the vulva. Enlarged udders were remarked in two cases. The extent of heat synchronization is evident from Fig. 3, which shows that 14 out of 15 heifers $(91 \%)$ came on heat on the third and fourth days after termination of hormone treatment. One heifer came on heat on the second day. All the heifers had normal corpora lutea 12-13 days after the synchronized oestrus.

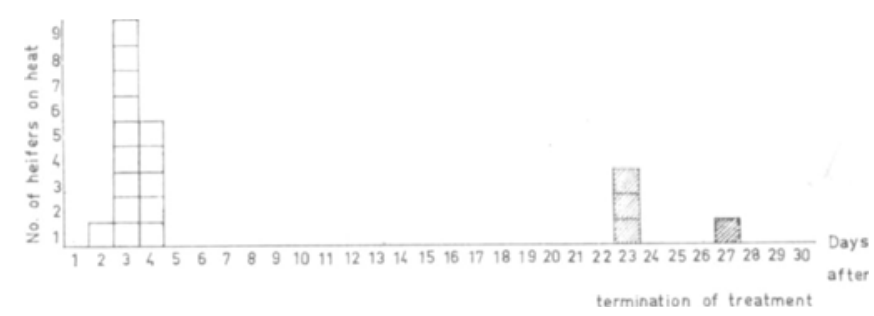

F igure 3. Distribution of heat and first returns after heat synchronization treatment of heifers with norethisterone in trial III.

From Table 2 it is clear that 10 out of $14(71.4 \%)$ heifers inseminated at the first heat became pregnant, and that a further three became pregnant following insemination at the second heat period after termination of hormone.

Three out of five heifers $(60 \%)$ returned on the 23rd day after termination of treatment. One of these, for technical reasons, had not been inseminated at the first heat. One heifer returned on the 27th day and another did not show any heat within the normal oestrus interval although she later proved to be nonpregnant.

\section{DISCUSSION}

These experiments demonstrate that norethisterone at levels of 0.6 and $1.0 \mathrm{mg} / \mathrm{kg}$ body weight per day effectively inhibits heat and ovulation in heifers. They further show that $0.2 \mathrm{mg} / \mathrm{kg}$ is 
too low a dose, since three out of 13 heifers came on heat during the period of treatment.

Several animals displayed a swollen vulva, mucus discharge, an open and reddened portio, and a contracted uterus during norethisterone treatment. Similar changes were observed when cattle were treated with progesterone by Ulberg et al. (1951), with MAP by Zimbelman (1963) and with MGA (melengestrol acetate) by Zimbelman \& Smith (1966). These were thought by the two latter workers to indicate that follicles which developed during treatment were oestrogen-producing. The changes in this investigation were most marked in the group receiving $0.2 \mathrm{mg} / \mathrm{kg}$ norethisterone, where follicle development was greatest.

Contrary to the results of experiments with progesterone (Ulberg \& Patterson 1954), MAP (Nellor et al. 1960) and CAP (Van Blake et al. 1963), an increased dose of norethisterone was not followed by a longer interval between the last day of treatment and the inception of oestrus. An explanation for this can be that norethisterone, apart from the fact that it is quickly metabolized in the animal body, has an oestrogenic effect which contributes to the appearance of heat symptoms.

A total of 51 out of 52 heifers $(98 \%)$ came on heat the third and fourth days after the termination of treatment with 0.6 and $1.0 \mathrm{mg} / \mathrm{kg}$ norethisterone.

The results can be compared with the best which have been obtained with other synthetic progesterones. The conception rate after first insemination varied between the groups from $41.7 \%$ to $71.4 \%$. The mean of $55 \%$ of the heifers pregnant after the first insemination is comparable with results from routine insemination of non-synchronized heifers.

Employing the low dose, $0.2 \mathrm{mg} / \mathrm{kg}$ resulted in not only poor oestrus synchronization, but also a low conception rate from the first heat after treatment. The result of palpation on the 9 th12th day after oestrus (no corpus luteum in three heifers and ovarian cysts in two) as well as the fact that $75 \%$ of the heifers repeated after abnormal intervals, suggests that follicle development after the termination of treatment was poorly controlled.

No relation between cycle phase and the interval between last day of treatment and the beginning of oestrus was seen in the $0.6-1.0 \mathrm{mg} / \mathrm{kg}$ groups. Similar observations were made regarding progesterone by Ulberg (1955) and Donker et al. (1958). Following treatment with the low dose of norethisterone $(0.2$ 
$\mathrm{mg} / \mathrm{kg}$ ), oestrus synchronization appears to be poorer if the administration of hormone began when the animals were in the luteal phase.

Whether the cycle phase had any effect on the conception rate could not be ascertained in this investigation. Collins et al. (1961) found no difference in fertility between heifers in different stages of the oestrus cycles when treatment with MAP began.

\section{ACKNOWLEDGMENTS}

The author wishes to express his thanks to Svensk Husdjursskötsel, Hållsta and Svenska Lantmännens Riksförbund, Stockholm for financial support of the work and to A.B. Astra, Södertälje for supplying norethisterone.

\section{REFERENCES}

Collins, W. E., L. W. Smith, E. R. Hauser \& L. E. Casida: Synchronization of estrus in heifers with 6 - $\alpha$-methyl-17- $\alpha$-acetoxyprogesterone and its effect on subsequent ovulation and fertility. J. Dairy Sci. 1961, 44, 1195.

Donker, J. D., J. R. Nichols, E. F. Graham \& W. E. Petersen: Controlled estrus in cattle. Proc. 3rd Sympos. Reprod. and Infertil. 1958, 171-178. Ed. F. X. Gassner, Pergamon Press.

Edgren, R. A., DeA. L. Peterson \& R. C. Jones: Some progestational and antifertility effects of norgestrel. Int. J. Fertil. 1966, 11, $389-400$.

Edgren, R. A., R. C. Jones \& DeA. L. Peterson: A biological classification of progestational agents. Fertil. and Steril. 1967, 18, $238-256$.

Lamond, D. R.: Synchronisation of ovarian cycles in sheep and cattle. Anim. Breed. Abstr. 1964, 32, 269-285.

Nellor, J. E., J. E. Ahrenhold \& R. H. Nelson: Influence of oral administration of 6-methyl-17-acetoxyprogesterone on follicular growth and estrous behavior in beef heifers. J. Animal Sci. 1960, 19, 1331.

Ulberg, L. C.: Synchronization of estrous cycles. Centennial Symp. Reprod. Infertil. 1955, 104-107. Michigan State Univ., East Lansing.

Ulberg, L. C., R. E. Christian \& L. E. Casida: Ovarian response in heifers to progesterone injections. J. Animal Sci. 1951, 10, 752759.

Ulberg, L. C. \& T. B. Patterson: The effect of progesterone upon certain reproductive processes in beef heifers. Proc. Ass. South agric. Workers 51st Anim. conf. 1954, 71.

Ulberg, L. C. \& C. E. Lindley: Use of progesterone and estrogen in the control of reproductive activities in beef cattle. J. Animal Sci. $1960,19,1132-1142$. 
Van Blake, H., M. A. Brunner \& W. Hansel: Use of 6-chloro- $\Delta^{6}$-dehydro17-acetoxyprogesterone (CAP) in estrous cycle synchronization of dairy cattle. J. Dairy Sci. 1963, 46, 459-462.

Wagner, J.F., J. W. McAskill \& T. M. Means: Synchronization of estrus in the bovine, J. Animal Sci. 1963, 22, 886.

Wiltbank, J. N. \& D. R. Zimmerman: Estrus synchronization and fertility in Hereford heifers subsequent to administration of progesterone and estradiol. J. Animal Sci. 1962, 21, 660.

Zimbelman, R. G.: Determination of the minimal effective dose of $6 \alpha$-methyl-17 $\alpha$-acetoxyprogesterone for control of the estrual cycle of cattle. J. Animal Sci. 1963, 22, 1051-1058.

Zimbelman, R. G. \& L. W. Smith: Control of ovulation in cattle with melengestrol acetate. J. Reprod. Fertil. 1966, 11, 193-201.

\section{SUMMARY}

Sixty-five heifers in different stages of the oestrus cycle were fed norethisterone once daily for 17 days at doses of $0.2,0.6$ and $1.0 \mathrm{mg} / \mathrm{kg}$ body weight.

During treatment swollen vulva, mucus discharge, open and reddened portio and udder enlargement were noted.

Norethisterone was effective in suppressing oestrus and ovulation at doses of 0.6 and $1.0 \mathrm{mg} / \mathrm{kg}$. Extremely good heat-synchronization followed the treatment and $98 \%$ of the heifers came on heat within a two-day period. Fifty-five \% conceived after the first insemination. In the group receiving $0.2 \mathrm{mg}$ norethisterone per $\mathrm{kg}$, three out of 13 heifers showed psychic heat during treatment. Poor heat synchronization and low conception rate were obtained in this group.

A possible effect of cycle stage on heat synchronization was noted only in the $0.2 \mathrm{mg}$ group where a better result was obtained when treatment began in the follicular phase.

\section{SAMMANFATTNING}

Brunstsynkronisering hos kvigor med hjälp av noretisteron.

Sextiofem kvigor i olika stadier av brunstcykeln utfodrades med noretisteron - 0,2, 0,6 och $1,0 \mathrm{mg}$ per $\mathrm{kg}$ kroppsvikt, en gång dagligen i 17 dagar.

Under behandlingen iakttogs svullen vulva, slemflytning, öppen och rodnad portio samt juverförstoring.

Noretisteron, 0,6 och 1,0 mg per kg, hämmade effektivt brunst och ovulation. Mycket god brunstsynkronisering följde på behandlingen och $98 \%$ av kvigorna blev brunstiga inom en tvådagars period. Femtiofem procent blev dräktiga efter första inseminationen. I gruppen som fick $0,2 \mathrm{mg}$ noretisteron per $\mathrm{kg}$ visade 3 av 13 kvigor psykisk brunst under behandlingen, som åtföljdes av dålig brunstsynkronisering och låg fertilitet.

En möjlig effekt av cyklusstadiet på brunstsynkroniseringen framkom endast i $0,2 \mathrm{mg}$ gruppen där bättre resultat erhölls när behandlingen började i follikelfas. 